\title{
Erratum to: Anal incontinence and quality of life following obstetric anal sphincter injury
}

\author{
Ranitha Kumar - Chun Ooi • Anthony Nicoll
}

Published online: 17 February 2012

(C) Springer-Verlag 2012

Erratum to: Arch Gynecol Obstet (2012)

285(3):591-597

DOI 10.1007/s00404-011-2003-x

We regret the omission of two authors Chun Ooi and Anthony Nicoll in the online published article. The complete author group is given below.

Ranitha Kumar · Chun Ooi · Anthony Nicoll

The online version of the original article can be found under doi:10.1007/s00404-011-2003-X.

R. Kumar $(\bowtie) \cdot$ C. Ooi · A. Nicoll

Obstetrics \& Gynaecology, Wishaw General Hospital,

40, The Fairways, Bothwell, Lanarkshire G71 8PA, UK

e-mail: ranithakumar@hotmail.com 